\title{
KELIMPAHAN BAKTERI HETEROTROF SEDIMEN PADA BERBAGAI TIPE KERAPATAN DI KAWASAN KONSERVASI MANGROVE DESA BEDONO, KECAMATAN SAYUNG, DEMAK
}

\author{
The Abudance of Sediment Heterotrophic Bacteria on Various Types of Vegetasion Density \\ in Mangrove Conservation Area Village Bedono Sayung, Demak
}

\author{
Siti Supriyati, Sutrisno Anggoro*) dan Niniek Widyorini \\ Program Studi Manajemen Sumberdaya Perairan Departemen Sumberdaya Akuatik \\ Fakultas Perikanan dan Ilmu Kelautan Universitas Diponegoro \\ J1. Prof. Soedharto, SH Semarang, Jawa Tengah - 50275, Telp/Fax. +6224 7474698 \\ sitisupriyati3742@gmail.com
}

\begin{abstract}
ABSTRAK
Kawasan mangrove di Desa Bedono Demak merupakan kawasan mangrove yang dijadikan tempat konservasi sekaligus sebagai tempat wisata. Hutan mangrove merupakan tempat berkembangnya berbagai bakteri, keberadaan bakteri memiliki arti yang sangat penting dalam proses dekomposisi pada sedimen. Informasi tentang hubungan kerapatan dengan jumlah bakteri heterotrof diperlukan untuk pengeloaan dan pengkajian lebih lanjut pada kawasan tersebut. Penelitian ini bertujuan untuk mengetahui kondisi kerapatan mangrove dan hubungannya terhadap kelimpahan bakteri heterotrof sedimen di kawasan konservasi mangrove Bedono. Penelitian ini dilaksanakan pada bulan Maret 2017 di kawasan konservasi mangrove Bedono, Demak. Sampel sedimen diambil pada masing-masing jenis kerapatan (jarang, sedang dan rapat) dengan 3 kali pengulangan, serta dibedakan pada saat pasang dan surut. Hasil yang didapat yaitu kerapatan mangrove pada kawasan konservasi mangrove Desa Bedono Demak yaitu 900 pohon/ha termasuk pada tingkat kerapatan jarang dengan kelimpahan rata-rata bakteri heterotrof sedimen $1,30 \times 10^{-5} \mathrm{cfu} / \mathrm{gr}$ pada saat pasang dan $0,97 \times 10^{-5} \mathrm{cfu} / \mathrm{gr}$ pada saat surut, 1.200 pohon/ha termasuk sedang dengan kelimpahan rata-rata bakteri heterotrof sedimen $0,65 \times 10^{-5} \mathrm{cfu} / \mathrm{gr}$ pada saat pasang dan $0,60 \times 10^{-5} \mathrm{cfu} / \mathrm{gr}$ pada saat surut, serta 2.400 pohon/ha termasuk kawasan mangrove rapat $1,32 \times 10^{-5} \mathrm{cfu} / \mathrm{gr}$ pada saat pasang dan $1,35 \times 10^{-5} \mathrm{cfu} / \mathrm{gr}$ pada saat surut. Diperoleh kesimpulan bahwa kelimpahan bakteri tidak berhubungan dengan kerapatan mangrove dengan nilai $p$-value sebesar $0,428\left(R=0,206\right.$ dan $\left.R^{2}=0,042\right)$.
\end{abstract}

Kata Kunci: Total Plate Count; Bakteri Heterotrof Sedimen; Mangrove Bedono Demak

\section{ABSTRAK}

Mangrove area in the Bedono village, Demak is a mangrove area used as a conservation place as well as a tourist attraction. Mangrove forest is a growing place of bacterias, the presence of bacteria has a very important role in the decomposition process of sediment. Information on the density relationship with the number of heterotrophic bacteria is required for the management and further assessment of the area. This study purpose is to determine the condition of mangrove density and its relationship to the abundance of sediment heterotrophic bacteria in Bedono mangrove conservation area. This research was conducted in March 2017 at Bedono mangrove conservation area, Demak. Sediment samples were taken on each density type (low, medium and high) with 3 repetitions, and differentiated at high and low tide. The results obtained are mangrove densities in the mangrove conservation area of Bedono village, 900 trees/ha included at low density levels with an average abundance of $1,30 \times 10^{-5} \mathrm{cfu} / \mathrm{gr}$ heterotrophic bacteria at high tide and $0,97 \times 10^{-5} \mathrm{cfu} / \mathrm{gr}$ at low tide, 1.200 trees/ha included at moderate with an average abundance of sediment heterotroph bacteria $0,65 \times 10^{-5}$ cfu/gr at high tide and $0,60 \times 10^{-5}$ cfu/gr at low tide, and 2.400 trees/ha included at dense mangrove area of $1,32 \times 10^{-5} \mathrm{cfu} / \mathrm{gr}$ at high tide and $1,35 \times 10^{-5} \mathrm{cfu} / \mathrm{gr}$ at low tide. It is concluded that bacterial abundance is not related to mangrove density with $p$-value amount at $0,428\left(R=0,206\right.$ and $\left.R^{2}=0,042\right)$.

Key Words: Total Plate Count; Sediment Heterotrophic Bacteria; Mangrove Bedono Demak

*) Penulis Penanggungjawab

\section{PENDAHULUAN}

Kawasan Taman Konservasi Mangrove Desa Bedono Kecamatan Sayung Demak merupakan kawasan mangrove yang dijadikan tempat konservasi sekaligus sebagai tempat wisata. Kawasan mangrove di Bedono memiliki areal yang cukup luas, ada yang berbatasan langsung dengan laut dan ada juga yang tumbuh pada daerah muara sungai.. Menurut Marfai et al., (2016), Dominasi mangrove yang ditemukan di area ini adalah Rhizophora sp. yang jangkauan akarnya ${ }^{\circ}$ Copyright by Management of Aquatic Resources (MAQUARES) 
meredam gelombang laut, oleh karena itu spesies ini tumbuh pada bagian luar delta. Jenis mangrove lainnya yang tumbuh yaitu Avicennia alba, Sonneratia sp. dan Bruguiera sp. Hastuti et al., (2009), Ekosistem mangrove di daerah Demak Jawa Tengah mengalami perubahan yang sangat cepat karena tidak stabilnya kondisi pantai pada daerah tersebut. Perkembangan pesisir disebabkan oleh perubahan dinamika hidrooceanografi yang telah mempengaruhi kerusakan pesisir. Ekosistem mangrove sebagai ekosistem alami tidak dapat berfungsi secara optimal dengan berkurangnya luas kawasan.

Mangrove merupakan tumbuhan yang memiliki ciri khusus yaitu dapat tumbuh pada lingkungan dengan salinitas antara air tawar dan air laut, Perairan laut mengandung $35 \mathrm{gr} / \mathrm{l}$ garam. Hal itu berarti bahwa perairan laut memiliki potensi osmotik sebesar 2,5 MPa, dan perairan harus menyesuaikan tekanan tersebut. Terkadang mangrove ditemukan pada daerah dengan kondisi hypersaline Persebaran varietas mangrove untuk mengatasi lingkungan yang tidak berpotensi, Prinsip mekanisme pengeluaran kadar garam dilakukan oleh akar, toleransi konsentrasi garam dan pengeluaran kadar garam melalui sekresi (Hogarth, 2007).

Ekosistem mangrove adalah ekosistem yang dominan di sepanjang garis pantai tropis. Ekosistem mangrove memiliki hubungan penting dengan peraturan dan optimalisasi lingkungan laut tropis. Aktivitas mikroba bertanggung jawab untuk transformasi nutrisi utama dalam ekosistem mangrove Telah didokumentasikan bahwa mikroorganisme memainkan peran penting dalam produktivitas, konservasi dan rehabilitasi ekosistem mangrove (Zhang et al., 2009). Menurut Mendes dan Siu (2014), dalam sedimen mangrove, mikroorganisme memainkan peran penting dalam pemulihan produktivitas, konservasi, dan lingkungan, dimana mereka berpartisipasi dalam siklus biogeokimia dan pemasok sumber energi bagi organisme hewan maupun tumbuhan.

Belum banyaknya penelitian yang dilakukan tentang kelimpahan bakteri heterotrof pada sedimen mangrove menjadikan kurangnya informasi tentang kelimpahan bakteri heterotrof pada sedimen mangrove dan juga hubungannya terhadap tipe kerapatan mangrove yabg berbeda. Oleh karena itu dilakukan penelitian ini untuk mengetahui apakah terdapat hubungan antara kelimpahan bakteri heterotrof dengan berbagai tipe kerapatan mangrove..

Tujuan penelitian ini antara lain adalah :

1. Kerapatan mangrove di Kawasan Konservasi Mangrove Desa Bedono Kecamatan Sayung Demak,

2. Kelimpahan bakteri heterotrof pada sedimen mangrove di Kawasan Konservasi Mangrove Desa Bedono Kecamatan Sayung Demak,

3. Hubungan antara kerapatan mangrove dengan kelimpahan bakteri heterotrof sedimen dan parameter lingkungan sedimen.

\section{MATERI DAN METODE PENELITIAN}

Materi

Materi penelitian ini adalah sampel sedimen mangrove pada beberapa tipe kerapatan yang berbeda (jarang, sedang dan rapat), serta parameter pendukung meliputi suhu sedimen, salinitas sedimen, bahan organik sedimen dan $\mathrm{pH}$ sedimen.

\section{Metode}

Metode yang digunakan untuk menghitung kerapatan mangrove mengacu pada Kepmen LH No. 201 Tahun 2004, setiap stasiun pengamatan dibuat kuadran dengan ukuran $10 \mathrm{~m}$ x $10 \mathrm{~m}$, pengambilan sampel sedimen dan pengukuran parameter fisika kimia berada dalam kuadran tersebut. Setiap stasiun mewakili vegetasi mangrove dengan kerapatan jarang, sedang dan rapat. Berikut merupakan rumus yang digunakan untuk menghitung kerapatan

Keterangan:

Rdi = Kerapatan

$\mathrm{ni} \quad=$ Jumlah tegakan jenis I

$\Sigma \mathrm{N} \quad=$ Jumlah total tegakan seluruh jenis

Pengambilan sampel dilakukan pada 3 stasiun pengamatan yang mewakili kerapatan yang berbeda (Jarang, sedang dan rapat) menggunakan paralon. Sampel yang telah diambil dimasukkan dalam stoples plastik lalu dibawa dengan coolbox sampai tempat analisis agar bakteri tidak berkembang terlalu pesat. Rentang waktu yang dibutuhkan dari pengambilan sampel sampai sampel akan dianalisis yaitu 6 jam dengan melihat tempat pengambilan sampel dan tempat analisis jauh. Sampel sedimen yang akan di uji bahan organiknya dimasukkan dalam plastik lalu dibawa dengan coolbox.

Suhu sedimen yang diukur menggunakan termometer air raksa dengan menenggelamkan termometer ke dalam sedimen secara horizontal dan didiamkan lalu diangkat perlahan untuk melihat suhu sedimen. Pengukuran suhu ini dilakukan secara in situ. Analisis pH dilakukan secara in situ di lapangan dengan langkah-langkah sebagai berikut: sampel sedimen diambil pada setiap stasiun, kertas saring yang telah dipotong kecil dimasukkan ke dalam spuit suntik $3 \mathrm{ml}$, kemudian sampel sedimen dimasukkan pada spuit suntik, lalu spuit suntik ditekan hingga keluar air dan diteteskan pada $\mathrm{pH}$ paper. Dilakukan pengamatan pada perubahan warna yang terjadi pada $\mathrm{pH}$ paper dengan membandingkannya pada indikator $\mathrm{pH}$. Pengukuran salinitas dilakukan menggunakan hand refractometer dengan meneteskan air yang berasal dari sedimen yang telah dimasukkan dalam spuit suntik berisi kertas saring, kemudian dilihat skala salinitas yang ada. Pengukuran salinitas ini dilakukan secara in situ. Pengukuran bahan organic sedimen dilakukan secara ex situ di laboratorium dengan metode LOI (Loss on Ignition) menurut Heiri et al., (2001).

Media Tryptone-Glucose-Yeast extract (TGY) terdiri atas 5,0 g tripton, 1,0 g glukosa, 2,5 g ekstrak yeast, 15,0 g agar dan $1.000 \mathrm{ml}$ akuades. Pembuatan media TGY dengan mencampurkan semua bahan, media TGY dihomogenisasi pada hotplate magnetic stirrer sampai mendidih, kemudian media disterilisasi di autoclave dengan suhu $121^{\circ} \mathrm{C}$ selama 15 menit 
pada tekanan 1 atm. Selanjutnya media dituangkan pada cawan petri dan didiamkan sampai padat dan dimasukkan dalam refrigator. Selanjutnya melakukan pengenceran seimen dengan menghomogenkan sedimen dengan air laut steril dengan perbandingan 1:9. Sebanyak $1 \mathrm{gr}$ sedimen dihomogenkan dengan $9 \mathrm{ml}$ air laut steril yang akan didapatkan pengenceran 10${ }^{1}$. $1 \mathrm{ml}$ dari $10^{-1}$ dimasukkan dalam $9 \mathrm{ml}$ air laut steril dan akan didapatkan pengenceran $10^{-2}$ dan seterusnya sampai pengenceran $10^{-5}$.

Isolasi dilakukan untuk menumbuhkan bakteri dari sampel yang telah diencerkan pada media TGY, metode isolasi menggunakan metode spread plate. Sebanyak $100 \mu$ sampel sedimen yang telah diencerkan ditanam pada media TGY, lalu diratakan dengan spreader steril. Sampel bakteri yang telah diisolasi pada media TGY diinkubasi selama 24 jam dalam inkubator bersuhu $37^{\circ} \mathrm{C}$. Perhitungan kelimpahan bakteri menggunakan metode TPC (Total Plate Count) dengan menggunakan rumus:

$$
\mathrm{A}=\frac{1}{\text { Volumen inokulasi }} \times \sum \text { koloni } x \sum \text { Pengenceran }
$$

Keterangan:

A $\quad$ Kelimpahan bakteri (cfu/gr)

Upk = Unit pembentuk koloni

\section{Analisis Data}

Analisis data pada penelitian ini dibantu menggunakan software SPSS Stastistics 16. Untuk melihat hubungan antara kerapatan mangrove dan pasang surut dengan kelimpahan bakteri heterotrof sedimen menggunakan analisis regresi berganda. Untuk mengetahui korelasi antara kerapatan mangrove dengan parameter lingkungan sedimen digunakan analisis korelasi Pearson.

\section{HASIL DAN PEMBAHASAN}

\section{Keadaan Umum Lokasi}

Penelitian dilakukan di Taman Konservasi Mangrove Desa Bedono Kecamatan Sayung Demak. Desa Bedono merupakan desa yang berada di daerah pesisir utara pulau Jawa dimana terdapat sungai besar yaitu sungai Sayung. Kawasan konservasi mangrove Desa Bedono berada pada perbatasan antara areal pertambakan dan perairan laut Jawa. Untuk mencapai lokasi konservasi hutan mangrove tersebut harus menggunakan perahu yang berasal dari Desa Bedono maupun dari Morosari. Mangrove yang berada di kawasan tersebut memiliki areal yang cukup luas dan beragam, dimana jenis mangrove yang mendominasi adalah jenis Api-api dan Bakau. Setiap kawasan memiliki keanaekaragaman yang berbeda, ada kawasan yang hanya terdapat jenis mangrove Api-api ataupun hanya terdapat jenis Bakau, namun ada pula kawasan yang ditumbuhi kedua jenis mangrove tersebut. Mangrove di Taman Konservasi Mangrove Desa Bedono Kecamatan Sayung Demak tersebut sebagian tumbuh alami dan sebagian ditanam oleh pemerintah maupun kelompok paguyuban di daerah Desa Bedono. Menurut Zaky et al., (2012), kondisi lahan mangrove Desa Bedono telah mengalami degradasi yang meliputi penurunan muka tanah, kenaikan muka air laut dan abrasi. Abrasi yang dialami mengakibatkan sejumlah kawasan mangrove dan pemukiman warga hilang dan rusak.

Lokasi penelitian pengambilan sampel sedimen di lakukan pada 3 stasiun dengan tingkat kerapatan yang berbeda (Jarang, sedang dan rapat). Stasiun 1 terletak pada koordinat 6 54'51.1 LS dan 110'29'13,2 BT dengan kerapatan tergolong jarang.Stasiun 2 terletak pada koordinat 6054'50.46 LS dan 110²9'12.69 BT dengan kerapatan tergolong sedang. Stasiun 3 terletak pada koordinat 654’49.77 LS dan 110²9’12.26 BT dengan kerapatan tergolong rapat.

\section{Kerapatan Mangrove}

Hasil perhitungan kerapatan mangrove yaitu terdapat 900 pohon/ha termasuk kerpatan jarang, 1.200 pohon/ha termasuk kerapatan sedang dan 2.400 pohon/ha termasuk rapat. Dapat dilihat pada tabel 1 mengacu pada Kepmen LH No. 201 Tahun 2004.

Tabel 1. Hasil Perhitungan Kerapatan Mangrove (Pohon/ha)

\begin{tabular}{cccc}
\hline Stasiun & Kerapatan (Pohon/ha) & Kriteria Baku Mutu & Pustaka \\
\hline I & 900 & $<1000$ (Jarang) & Kepmen LH No. \\
II & 1.400 & $\geq 1000-<1500$ (Sedang) & 201 Tahun 2004 \\
III & 2.400 & $\geq 1500$ (Rapat) & \\
\hline
\end{tabular}

Berdasarkan hasil pengukuran dan perhitungan yang telah dilakukan untuk mengetahui kerapatan mangrove di Taman Konservasi Mangrove Desa Bedono Sayung Demak, pada kawasan penelitian hanya terdapat vegetasi mangrove jenis Avicennia sp. dengan kerapatan jarang (900 pohon/ha), sedang (.1200 pohon/ha) dan rapat (2.400 pohon/ha). Masingmasing kerapatan memiliki kondisi lingkungan yang berbeda, termasuk pengaruhnya terhadap kelimpahan bakteri heterotrof pada sedimen mangrove.

Kawasan ekosistem mangrove di daerah Demak khususnya dan seluruh kawasan mangrove pada umumnya merupakan ekosistem yang rentan terhadap kerusakan secara alami maupun disebabkan oleh manusia. Kawasan mangrove di Desa Bedono Sayung Demak memiliki areal yang cukup luas namun sudah mengalami banyak kerusakan karena kondisi alam juga disebabkan oleh manusia. Menurut penelitian yang telah dilakukan oleh Hastuti et al., (2009), Ekosistem mangrove di daerah Demak Jawa Tengah mengalami perubahan yang sangat cepat karena tidak stabilnya kondisi pantai 
pada daerah tersebut. Perkembangan pesisir disebabkan oleh perubahan dinamika hidrooceanografi yang telah mempengaruhi kerusakan pesisir. Ekosistem mangrove sebagai ekosistem alami tidak dapat berfungsi secara optimal dengan berkurangnya luas kawasan.

Mangrove merupakan ekosistem yang paling kaya karena memiliki banyak fungsi secara ekologis maupun sosial, ekosistem mangrove sangat mendukung dalam kehidupan organisme yang hidup di dalamnya. Keberadaan mangrove juga sangat bermanfaat untuk ekosistem lain seperti lamun dan terumbu karang. Ekosistem mangrove juga dapat berfungsi sebagi pelindung abrasi, gelombang dan tsunami. Menurut Fathurrohmah et al.,(2013), sebagai salah satu ekosistem wilayah pesisir, hutan mangrove memiliki fungsi ekologis, fungsi sosial dan ekonomis, serta fungsi fisik. Hutan mangrove merupakan daerah tempat hidup dan mencari makan (feeding ground) bagi berbagai organisme seperti udang, kepiting, ikan, burung, dan mamalia. Selai itu, secara ekologis hutan mangrove juga menyediakan tempat yang sangat baik dan ideal bagi proses pemijahan (spawning ground) biota laut yang ada di dalamnnya.

Kerapatan mangrove dalam ekosistem memiliki peran penting dalam proses dekomposisi serasah mangrove, semakin rapat kawasan mangrove maka serasah yang dihasilkanpun akan meningkat, dengan demikian proses dekomposisi pada kawasan tersebut juga lebih tinggi dibandingkan dengan kawasan dengan kerapatan yang lebih rendah. Namun, berdasarkan hasil penelitian yang telah dilakukan didapatkan hasil bahwa kerapatan tidak berpengaruh terhadap kelimpahan bakteri heterotrof pada sedimen mangrove, hal ini berarti laju dekomposisi dalam sedimen mangrove tidak dipengaruhi oleh kerapatan vegetasi mangrove. Menurut Widhitama et al., (2016), Tingkat kerapatan memiliki faktor penting dalam menentukan tinggi rendahnya produksi serasah yang jatuh kedalam ekosistem mangrove. Serasah mangrove merupakan hal penting yang dapat digunakan oleh ekosisten untuk menciptakan suatu rantai makan dimana hal ini dimulai dari proses dekomposisi serasah mangrove, serasah mangrove yang terdekomposisi kemudian akan digunakan oleh mikroorganisme yang menggunakan serasah tersebut untuk bahan makanan. Menurut Arta et al., (2009), Kerapatan mangrove dengan kandungan serasah mangrove memiliki hubungan korelasi yang sangat kuat.

\section{Total Bakteri Heterotrof Sedimen}

Hasil perhitungan rata-rata total bakteri heterotrof sedimen tersaji dalam tabel 2.

Tabel 2. Hasil Perhitungan Kelimpahan Rata-rata Total Bakteri Heterotrof (cfu/g) pada Sedimen Mangrove

\begin{tabular}{ccc}
\hline Stasiun & $\begin{array}{c}\text { Rata-rata } \\
\text { Bakteri Pasang }\end{array}$ & $\begin{array}{c}\text { Rata-rata } \\
\text { Bakteri Surut }\end{array}$ \\
\hline I & $1,30 \times 10^{-5}$ & $0,97 \times 10^{-5}$ \\
II & $0,65 \times 10^{-5}$ & $0,60 \times 10^{-5}$ \\
III & $1,32 \times 10^{-5}$ & $1,35 \times 10^{-5}$ \\
\hline
\end{tabular}

Berdasarkan perhitungan yang telah dilakukan untuk melihat hubungan antara total bakteri heterotrof dengan pasang surut diperoleh hasil bahwa nilai $\mathrm{T}$ hitung $<\mathrm{T}$ tabel $=-0,015<1,753$ dengan nilai $p$-value sebesar $0,989(\mathrm{R}=0,206$ dan $\mathrm{R}^{2}=0,042$ ). Hal ini berati bahwa Ho diterima dan kesimpulannya yaitu tidak ada hubungan antara pasang-surut dengan kelimpahan bakteri heterotrof sedimen.

Hubungan antara kerapatan mangrove dengan kelimpahan bakteri heterotrof pada sedimen mangrove menggunakan regresi linier berganda didapatkan hasil bahwa nilai T hitung $<\mathrm{T}$ tabel $=0,815<1,753$ dengan nilai $p$-value sebesar 0,428 $\left(\mathrm{R}=0,206\right.$ dan $\left.\mathrm{R}^{2}=0,042\right)$. Hal ini berarti bahwa Ho diterima dan kesimpulannya yaitu tidak ada hubungan antara kerapatan mangrove dengan kelimpahan bakteri heterotrof sedimen mangrove.

Kelimpahan bakteri pada sedimen tinggi karena bakteri pada sedimen berperan dalam proses dekomposisi. Pengambilan sampel sedimen dilakukan pada jenis kerapatan jarang, sedang dan tinggi. Kelimpahan bakteri pada kerapatan jarang, sedang dan rapat memiliki hasil yang berbeda, pada kerapatan jarang dan sedang kelimpahan bakteri lebih tinggi dibandingkan pada kerapatan sedang. Hal ini dapat dipengaruhi oleh letak masing-masing jenis kerapatan, dimana lokasi pada kerapatan jarang dan rapat berbatasan langsung dengan sungai yang dapat langsung terpengaruh oleh perubahan-perubahan lingkungan seperti terkena pasang lebih cepat dan terjadi sedimentasi lebih tinggi dibandingkan pada lokasi kerapatan sedang yang letaknya lebih masuk. Perkembangan mangrove dan kondisi sedimennya akan selalu mengalami dinamika perubahan baik yang diakibatkan oleh sedimentasi yang berasal dari air yang menggenang maupun campurannya dengan serasah sehingga membentuk lahan mangrove yang kaya akan bahan organik (Purnomo et al., 2016).

Berdasarkan hasil penelitian yang telah dilakukan, hasil yang diperoleh yaitu kerapatan mangrove tidak berhubungan dengan kelimpahan bakteri heterotrof pada sedimen mangrove. Secara umum produksi bahan organik ditentukan oleh jenis dan kerapatan tegakan hutan mangrove, dimana semakin rapat tegakan produksi bahan organik juga meningkat, sedangkan dekomposisi juga ditentukan oleh jenis bahan organik maupun oleh faktor dekomposernya. C/N rasio merupakan ukuran dari proses dekomposisi bahan organik, sementara bakteri merupakan suatu komponen yang melaksanakan kegiatan dekomposisinya. Hasil analisis tersebut di atas menunjukkan bahwa semakin meningkat total bakteri yang ditemukan menunjukkan terjadinya penurunan $\mathrm{C} / \mathrm{N}$ rasio (Purnomo et al., 2016). Hal ini menunjukkan bahwa semakin rapat tegakan mangrove maka bahan organik yang ada juga meningkat, sedangkan meningkatnya total bakteri menunjukkan penurunan $\mathrm{C} / \mathrm{N}$ rasio. Jadi kerapatan mangrove dengan total bakteri berbanding terbalik. Menurut Arta et al., (2009), Kerapatan mangrove dengan jumlah koloni bakteri memiliki hubungan yang cukup kuat dan arah hubungannya adalah negatif. 
Kelimpahan bakteri yang terdapat pada sedimen lebih tinggi dibandingkan dengan yang ada di air, hal ini dikarenakan proses akumulasi bahan organik di sedimen, dengan demikian proses dekompisi untuk merombak bahan organik terjadi lebih tinggi pada sedimen dibandingkan pada air. Hal ini diperkuat oleh Mahalaksmi et al., (2011), Populasi THB (Total Heterotrophic Bacteria) dan bakteri patogen lebih tinggi pada sedimen dibandingkan pada air, sedimen pesisir memerankan peran penting pada proses demineralisasi bahan organik yang mendukung pertumbuhan mikroba. Populasi bakteri pada sedimen lebih tinggi dibandingkan pada air pada umumnya karena kandungan organik pada air lebih dinamis dibandingkan pada sedimen.

Parameter Lingkungan Sedimen

Hasil parameter lingkungan sedimen yang tersaji dalam tabel 3 .

Tabel 3. Hasil Pengukuran Parameter Lingkungan

\begin{tabular}{lcc}
\hline & Parameter Lingkungan & Rerata \pm SD \\
\hline \multirow{4}{*}{ Pasang } & Suhu Sedimen $\left({ }^{\circ} \mathrm{C}\right)$ & $29,33 \pm 0,50$ \\
& pH Sedimen & $7,89 \pm 0,60$ \\
& Salinitas Sedimen (ppt) & $24,57 \pm 2,70$ \\
& Bahan Organik sedimen $(\%)$ & $65,99 \pm 3,84$ \\
\hline \multirow{3}{*}{ Surut } & Suhu Sedimen $\left({ }^{\circ} \mathrm{C}\right)$ & $29,44 \pm 0,53$ \\
& pH Sedimen & $8,00 \pm 0,71$ \\
& Salinitas Sedimen (ppt) & $24,78 \pm 2,44$ \\
& Bahan Organik sedimen $(\%)$ & $67,22 \pm 2,72$ \\
\hline
\end{tabular}

Keterangan : SD = Standar Deviasi

Tabel 4. Output Person Corellations

\begin{tabular}{lrrrrr}
\hline & $\begin{array}{c}\text { Kerapatan } \\
\text { Mangrove }\end{array}$ & $\begin{array}{c}\text { Bahan Organik } \\
\text { Sedimen }\end{array}$ & $\begin{array}{c}\text { Salinitas } \\
\text { Sedimen }\end{array}$ & pH Sedimen & $\begin{array}{c}\text { Suhu } \\
\text { Sedimen }\end{array}$ \\
\hline Kerapatan Mangrove & 1,000 &, 674 &,- 699 &,- 124 &, 158 \\
Bahan Organik &, 674 & 1,000 &,- 342 &, 138 &,- 093 \\
Sedimen & &,- 342 & 1,000 &, 172 &,- 313 \\
Salinitas Sedimen &,- 699 &, 138 &, 172 & 1,000 &,- 112 \\
pH Sedimen &,- 124 &,- 093 &,- 313 &,- 112 & 1,000 \\
Suhu Sedimen &, 158 & & & & \\
\hline
\end{tabular}

Berdasarkan hasil yang telah diperoleh, untuk mengetahui hubungan kerapatan vegetasi mangrove dengan parameter lingkungan sedimen dilakukan uji korelasi. Hasil perhitungan statistik hubungan kerapatan mangrove dengan parameter lingkungan sedimen adalah sebagai berikut: korelasi kerapatan mangrove dengan bahan organik sedimen 0,674 menunjukkan korelasi positif yang signifikan, artinya kerapatan mangrove berpengaruh sebesar $67,4 \%$ terhadap bahan organik pada sedimen mangrove atau semakin tinggi kerapatan vegetasi mangrove maka semakin tinggi pula bahan organic sedimen pada mangrove. Korelasi kerapatan mangrove dengan salinitas sedimen 0,699 menunjukkan korelasi negatif yang signifikan, artinya kerapatan mangrove berpengaruh sebesar 69,9\% secara negatif terhadap salinitas sedimen atau dengan kata lain semakin tinggi kerapatan maka salinitas semakin rendah. Korelasi kerapatan mangrove dengan $\mathrm{pH}$ sedimen 0,124 menunjukkan korelasi negatif, artinya kerapatan mangrove berpengaruh sebesar $12,4 \%$ secara negatif terhadap $\mathrm{pH}$ sedimen. Korelasi kerapatan mangrove dengan suhu sedimen 0,158 menunjukkan korelasi positif, artinya kerapatan mangrove berpengaruh sebesar $15,8 \%$ terhadap suhu sedimen.

Kerapatan mangrove mempengaruhi cahaya yang masuk pada permukaan sedimen dan juga akan berpengaruh terhadap parameter lingkungan yang lain seperti suhu sedimen, bahan organik dan $\mathrm{pH}$ sedimen serta salinitas. Berdasarkan hasil pengukuran yang telah dilakukan, kerapatan mangrove memiliki korelasi negatif yang signifikan terhadap salinitas sedimen. Semakin rapat vegetasi mangrove maka salinitas semakin mengalami penurunan. Menurut Arief (2003), Kerapatan pohon mampu meredam atau menetralisir peningkatan salinitas, karena perakaran yang rapat akan menyerap unsur-unsur yang mengakibatkan meningkatnya salinitas. Bentuk-bentuk perakaran yang telah beradaptasi terhadap suasana salinitas tinggi menyebabkan tingkat salinitas di daerah sekitar tegakan menurun. Penurunan tingkat salinitas juga disebabkan oleh terjadinya pengenceran air di dalam tanah pada waktu surut. Diperkirakan, tingkat frekuensi pasang surut sangat ikut menentukan adanya perubahan salinitas. Semakin sering terjadi pasang surut, tingkat salinitas semakin meningkat.

Ekosistem mangrove memiliki sedimen yang kaya akan bahan organik dan sebagai sumber makanan bagi organisme lain. Sedimen mangrove menjadi tempat terjadinya dekompoisi, mineralisasi dan siklus rantai makanan. Penelitian sebelumnya menyatakan bahwa sedimen mangrove terdiri dari kondisi anaerobik sebagai komponen utama dan sedikit lapisan aerobik pada sedimen. Degradasi bahan organik umunya terjadi pada zona aerobik melalui respirasi aerobik sedangkan pada lapisan anaerobik terjadi dekomposisi melalui redukssi sulfat (Sahoo dan Dhal, 2009). 
Kerapatan vegetasi mangrove yang berbeda memiliki hubungan terhadap bahan organik sedimen, dimana pada kerapatan yang rapat memiliki bahan organik yang tinggi yang disebakan oleh produksi serasah daun mangrove. Daun mangrove yang jatuh akan menjadi serasah dan nantinya kan mengalami proses dekomposisi oleh organisme mikro. Kerapatan mangrove akan berpengaruh terhadap serasah daun yang ada di permukaan sedimen sehingga dapat mempengaruhi konsentrasi bahan organik yang dihasilkan yang berpengaruh juga terhadap proses dekomposisi pada sedimen mangrove. Pertumbuhan mangrove yang baik di suatu pesisir pantai berkaitan dengan proses dekomposisi dari bahan organik yang dihasilkan oleh serasah daun mangrove. Proses dekomposisi berkaitan dengan jumlah dari bahan organik, rasio $\mathrm{C} / \mathrm{N}$ dan jumlah total bakteri yang terdapat pada substrat pohon mangrove di wilayah pantai desa Tambakbulusan (Hutama et al., 2016).

Kondisi lingkungan wilayah mangrove sangat mempengaruhi aktifitas mikroorganisme, termasuk bakteri heterotrof pada sedimen. $\mathrm{pH}$ adalah salah satu contohnya, dimana nilai $\mathrm{pH}$ juga terpengaruh oleh masukan materi dari ekosistem lain dan kondisi sedimen itu sendiri. Hubungan $\mathrm{pH}$ sedimen dengan kerapatan tidak kuat sehingga dapat dikatakan kerapatan mangrove tidak berhubungan dengan $\mathrm{pH}$ sedimen mangrove, namun nilai $\mathrm{pH}$ sedimen dapat mempengaruhi kelangsungan hidup mikroorganisme dalam sedimen. Nilai $\mathrm{pH}$ yang telah diukur pada masing-masing stasiun pengamatan yaitu berkisar antara 7-9. Kisaran nilai $\mathrm{pH}$ yang cocok untuk kehidupan organismne yaitu 6,5-8,5, walaupun dalam kondisi asam dan alkalin sebagian organisme masih dapat toleran. Kisaran $\mathrm{pH}$ untuk pertumbuhan dalam penelitian Haouari et al., (2006) yaitu nilai $\mathrm{pH}$ optimum untuk pertumbuhan adalah $7 \mathrm{dan} \mathrm{pH}$ pertumbuhan umumnya antara 6,0-8,1. Menurut Suriani et al., (2013), Salah satu faktor panting dalam pertumbuhan bakteri adalah nilai $\mathrm{pH}$. Bakteri memerlukan suatu $\mathrm{pH}$ optimum (6,5 $7,5)$ untuk tumbuh optimal. Nilai $\mathrm{pH}$ minimum dan maksimum untuk pertumbuhan kebanyakan spesies bakteri adalah 4 dan 9. Pengaruh $\mathrm{pH}$ terhadap pertumbuhan bakteri ini berkaitan dengan aktivitas enzim. Jika keasaman tanah berlebihan, maka akan mengakibatkan tanah sangat peka terhadap proses biologi. Proses dekomposisi bahan organik pada umumnya akan mengurangi suasana asam (Arief, 2003). Menurut Hapit et al., (2009), pH bersifat netral atau basa menunjukkan bahwa terjadi proses penguraian bahan organik yang sedikit dan oksigen terlarut yang tersedia dalam jumlah yang cukup.

\section{KESIMPULAN}

1. Kerapatan mangrove pada Taman Konservasi Mangrove Desa Bedono Kecamatan Sayung Demak yaitu 900 pohon/ha termasuk pada tingkat kerapatan jarang, 1.200 pohon/ha termasuk sedang dan 2.400 pohon/ha termasuk kawasan mangrove rapat.

2. Kelimpahan rata-rata bakteri heterotrof pada sedimen mangrove per 1 gram sampel pada kerapatan jarang, sedang dan rapat yaitu berkisar antara $0,60 \times 10^{-5}-1,35 \times 10^{-5} \mathrm{cfu} / \mathrm{gr}$.

3. - Kerapatan mangrove tidak berhubungan dengan kelimpahan bakteri heterotrof pada sedimen dengan nilai $p$-value sebesar 0,428. Nilai $R$ 0,206 dengan $R^{2}$ sebesar 0,042 .

- Kerapatan berhubungan signifikan secara positif terhadap bahan organik sedimen dengan korelasi $67,4 \%$, kerapatan berhubungan signifikan secara negatif terhadap salinitas sedimen dengan korelasi $69,9 \%$ dan korelasi kerapatan dengan suhu dan $\mathrm{pH}$ sedimen tidak signifikan dengan nilai masing-masing $15,8 \%$ dan $12,4 \%$.

\section{UCAPAN TERIMAKASIH}

Tulisan ini merupakan bagian dari laporan penelitian. Terimakasih juga kepada keluarga, teman-teman MSP 2013, dan semua pihak yang selalu mendukung dan membantu dalam pross penyusunan laporan penelitian ini.

\section{DAFTAR PUSTAKA}

Arief, A. M. P., 2003. Hutan Mangrove Fungsi dan Manfaatnya. Penerbit Kanisius, Yogyakarta.

Arta, A. P., A. Maidie dan G. Saptiani. 2009. Pengaruh Kerapatan Vegetasi Mangrove terhadap Populasi Bakteri Vibrio sp. di Pesisir Bontang. Jurnal Kehutanan Tropika Humida. 2 (2):133-142.

Fathurrohmah, S., K. B. Hati, B. Marjuki. 2013. Aplikasi Penginderaan Jauh untuk Pengelolaan Hutan Mangrove sebagai Salah Satu Sumberdaya Wilayah Pesisir (Studi Kasus di Delta Sungai Wulan Kabupaten Demak). Seminar Nasional Pendayagunaan Informasi Geospatial. ISBN: 978-979-636-152-6.

Haouari, O., M. L. Fardeau, L. Casalot, J. L. Tholozan, M. Hamdi, B. Olliver. 2006. Isolation of sulfate-reducing bacteria from Tunisian marine sediments and description of Desulfovibrio bizertensis sp. International Journal of Systematic and Evulotionary Microbiology. $56: 2909-2913$.

Hapit, A., A. Maidie dan G. Septiani. 2009. Populasi Bakteri Vibrio Sp. Berpendar pada Berbagai Pemanfaatan Lahan Mangrove di Wilayah Perairan Bontang. Jurnal Kehutanan Tropika Humida. 2 (1): 1-11.

Hastuti, E. D., S. Anggoro dan R. Pribadi. The Effects of Environmental Factors on the Dynamic Growth Pattern of Mangrove Avicennia Marina. Journal of Coastal Development. 16 (1) : 57-61.

Heiri, O., A. F. Lotter, dan G. Lemcke. 2001. Loss on Ignition as a Method for Estming Organic and Carbonate Content in Sediment: Reproducibility and Comparability of Result.Journal of Paleolimnology. 25: 101-110. 
Hogarth, P. J. 2007. The Biology of Mangroves and Seagrasses. Oxford University Press, New York.

Hutama, Y. P., P. W. Purnomo dan M. Nitisupardjo. 2016. Studi tentang Potensi Mangrove Desa Tambakbulusan berdasarkan Hubungan antara Sebaran Tingkat Kerapatan, C/N Ratio dan Total Bakteri. 5 (1) : 1-7.

Mahalaksmi, M., M. Srinivasan, M. Murugan, S. Balakrishnan, K. Devanathan. 2011. Isolation and Identification of Total Heterotrophic Bacteria and Human Pathogens in water and Sediment from Cuddalore fishing Harbour after the Tsunami. Asian Journal of Biological Sciences. 4 (2) : 148-156.

Marfai, M. A., D. W. Tyas, I. Nugraha, A. Fitriatul'ulya, W. Riasasi. 2016. The Morphodynamic of Wulan Delta and Its Impact on the Coastal Community in Wedung Subdistrict, Demak Regency, Indonesia. Journal of Enviromental Protection. $7: 60-71$.

Mendes, L., S. M. Tsai. 2014. Variations of Bacterial Community Structure and Composition in Mangrove Sediment at Different Depths in Southeastern Brazil. Diversity. 6 : 827-843.

Purnomo, P. W., N. Widyorini dan C. Ain. 2016. Analisis C/N Rasio dan Total Bakteri pada Sedimen Kawasan Konservasi Mangrove Sempadan Sungai Betahwalang dan Sungai Jajar Demak. Prosiding Seminar Nasional Tahunan ke-V Hasil-Hasil Penelitian Perikana dan Kelautan.

Sahoo, K. dan N. K. Dhal. 2009. Potential Micribial Diversity in Mangrove Ecosystem : a Review. Indian Journal of marine Sciences. 38 (2) : 249-256.

Suriani, S., Soemarno, Suharjono. 2013. Pengaruh Suhu dan pH terhadap Laju pertumbuhan Lima Isolat Bakteri Anggota Genus Pseudomonas yang diisolasi dari Ekosistem Sungai Tercemar Deterjen di sekitar Kampus Universitas Brawijaya. J-PAL. 3 (2).

Widhitama, S., P. W. Purnomo dan A. Suryanto. 2016. Produksi dan Laju Dekomposisi Serasah Mangrove berdasarkan Tingkat Kerapatannya di Delta Sungai Wulan, Demak, Jawa Tengah. Diponegoro Journal of Maquares. 5 (4) : 311 319.

Zaky, A. R., C. A. Suryono dan R. Pribadi. 2012. Kajian Kondisi Lahan Mangrove di Desa Bedono, Kecamatan Sayung, Kabupaten Demak dan Kelurahan Mangunharjo, Kecamatan Tugu, Kota Semarang. Journal of marine Research. 1 (2) : 88-97.

Zhang, Y., J. Dong, B. Yang, J. Ling, Y. Wang, S. Zhang. 2009. Bacterial Community Structure of Mangrove Sediments in Relation to Environmental Variables Accessed by $16 S$ rRNA Gene-denaturing Gradient Gel Electrophoresis Fingerprinting. Scientia Marina. 73 (3). 